\title{
Józef Tarnowski*
}

\section{Estetyka Stanisława Witkiewicza z dzisiejszej perspektywy}

DOI: http://dx.doi.org/10.12775/LC.2018.005

\begin{abstract}
Streszczenie: Stanisław Witkiewicz był twórcą wszechstronnym: zajmował się malarstwem, architekturą, literaturą, krytyką artystyczną, estetyką, etyką, myślą polityczną. W artykule analizowane są dwie sfery jego poglądów: na temat malarstwa i architektury w kontekście jego twórczości w tych dziedzinach sztuki. Ich wspólnym fundamentem było dążenie do patriotycznego nacechowania tych dziedzin sztuki. Po klęsce powstania styczniowego sztuka polska, najpierw poezja i muzyka, zaczęła pełnić rolę substytutu państwa w utrzymywaniu tożsamości narodowej, ożywianiu dążeń suwerennościowych i zaświadczaniu przed zagranicą o istnieniu polskiej kultury, a więc i polskiego narodu, jako słusznej podstawy do odzyskania własnego państwa. W dziedzinie estetyki i krytyki malarstwa stał się Witkiewicz rzecznikiem młodych malarzy, w tym i siebie jako malarza, dążących - z powodzeniem, jak się potem okazało - do dorównania malarstwu zachodnioeuropejskiemu. Jako estetyk architektury był twórcą opartej na dziedzictwie budownictwa ludowego górali podhalańskich koncepcji i praktyki stylu zakopiańskiego, który stał się pierwszym narodowym stylem w architekturze polskiej. Poglądy Witkiewicza w omówionych sferach pod pewnymi względami zachowują ciągle walor aktualności.
\end{abstract}

Słowa klucze: architektura, estetyka, malarstwo, patriotyzm

\section{Contemporary view on the aesthetics of Stanisław Witkiewicz}

\begin{abstract}
Stanisław Witkiewicz was a multi-talented artist: he was active in the field of paintings, architecture, literature, criticism of art, aesthetics, ethics and politics. In this paper the two areas of his thought - concerning paintings and architecture - have been analyzed in the context of his works
\end{abstract}

\footnotetext{
* Dr hab., profesor Uniwersytetu Gdańskiego, historyk estetyki. E-mail: jozef.tarnowski@ug.edu.pl.
} 
in both fields. The common base in both areas was the desire to mark them with patriotism. After the downfall of January Uprising the Polish art - in the beginning the poetry and music - started to play the role of the substitute of the state in order to maintain the national identity, stimulate the desire for independence and testify abroad that Polish culture and nation still exist; this was considered as a solid base for reconstruction of own state. In the area of aesthetics and criticism of painting Witkiewicz became a supporter of young painters - and himself as well - who tried to chase and equal (successfully) the achievements of the painters from Western Europe. As a critic of architecture Witkiewicz was the founder of the concept and practice of Zakopane architectural style, which was based on the legacy of rural constructions of Podhale highlanders and which became the first national style in Polish architecture. The opinions of Witkiewicz in mentioned areas are to some extend still valid also nowadays.

Keywords: aesthetics, architecture, painting, patriotism

tanisław Witkiewicz jako pisarz zajmował się zazwyczaj wieloma zagadnieniami równocześnie, ale różnym fazom swojej twórczości nadał odmienne dominanty. Swoje dzieło pisarskie rozpoczął pracami z estetyki i krytyki malarstwa, potem poświęcił się przede wszystkim architekturze, zaś ostatnie lata życia spędził głównie na zgłębianiu problematyki polityczno-społeczno-etycznej. Jego poglądy na temat malarstwa i architektury były ściśle związane z tworzoną przezeń sztuką: obrazami olejnymi i projektami domów w stylu zakopiańskim. Zasadnicze więc pytanie związane z poglądami Witkiewicza, jakie można im zadać po stu latach od jego śmierci, jest takie - czy się zestarzały, zdezaktualizowały, czy przeciwnie, są nadal żywe i aktualne, a jeśli tak, to w jakim sensie? Aby na to pytanie odpowiedzieć, trzeba poglądy Witkiewicza choćby skrótowo zrekonstruować.

\section{Malarstwo prawdy artystycznej}

Rodzina Witkiewiczów za udział w powstaniu styczniowym została przez władze carskie wydziedziczona ze swego majątku - Poszawsza na Żmudzi - i zesłana do Tomska na Syberii. Dwunastoletni Stanisław w walkach powstańczych udziału rzecz jasna nie brał, ale dostarczał ukrytym w lesie powstańcom proch i prowiant. Po czterech latach zsyłki udał się do Petersburga, by wyjednać u władz carskich objęcie jego rodziny amnestią. Misja zakończyła się powodzeniem, jednak ojciec nie wytrzymał trudów podróży i zmarł w czasie uciążliwej drogi z Tomska do Petersburga. Matka z córkami Marią i Barbarą oraz synem Janem osiedlili się w niewielkim majątku w Urdominie w Augustowskiem (obecnie na Litwie, blisko granicy z Polską), który matka odziedziczyła po swej siostrze (Piasecki 1983: 58). Rozbudzony patriotycznie Stanisław przeżył w kraju wielkie rozczarowanie, widząc martwotę i „wytrzeźwienie” społeczeństwa z niepodległościowych dążeń (Kosiński 1928: 14). Postanowił wówczas zostać malarzem i w tym celu udał się do Petersburga, gdzie wstąpił do akademii sztuk pięknych, by przyszłą działalnością artystyczną przyczynić się do ożywienia świadomości narodowej. Do akademii został przyjęty na podstawie egzaminu z rysunku, 
matura nie była wówczas wymagana. Rysować nauczył się w Tomsku od zesłańca Juliusza Flecka, litografa i rysownika z Warszawy (Piasecki 1983: 47).

W akademii szybko zniechęcił się do obowiązującej tam neoklasycystycznej doktryny, ale znalazł inne, bardziej dla niego interesujące zajęcie - studiowanie rysunków z kolekcji króla Stanisława Augusta, gromadzonej przed rozbiorami z myślą o założeniu „malarni” na Zamku Królewskim w Warszawie, a wywiezionej potem przez zaborcę do Rosji i udostępnianej studentom petersburskiej akademii. Wedle zachowanych listów do rodziny podjął wówczas decyzję, by poświęcić się patriotycznemu malarstwu historycznemu, i w tym celu po dwóch latach spędzonych w Petersburgu udał się do Krakowa, aby uczyć się takiego malarstwa od Jana Matejki (ibid.: 66). Jednakże z powodów nieznanych biografom zamiast tego wyjechał do Monachium, gdzie podjął dalsze studia na tamtejszej akademii sztuk pięknych. W uczelni tej, w odróżnieniu od akademii petersburskiej, panował pluralizm; byli tam zwolennicy akademickiego historyzmu, ale także antyakademickiego, courbetowskiego realizmu. Kolonii polskich studentów przewodził artystycznie Maksymilian Gierymski, którego powiedzenie „Matejko to nie malarz” stało się hasłem bojowym integrującym tę grupę. Podłożem owej postponującej Matejkę oceny był żywiony przez członków polskiej kolonii malarskiej w Monachium ideał iluzjonistyczny, wywiedziony z Leonardowskiego Traktatu o malarstwie, a egzemplifikowany współcześnie przez kontynuatorów Courbeta. Maks Gierymski już w młodym wieku zdobył pozycję wybitnego malarza realistycznego. Z perspektywy tego iluzjonistycznego ideału zarzucał on malarstwu krakowskiego mistrza pewne niedociągnięcia w perspektywie i światłocieniu, a także to, że zawiłość treści historycznych sprawia, że jego dzieła są poza Polską niezrozumiałe (Sygietyński 1951: 319). Witkiewicz uległ wpływowi Gierymskiego. Po dwóch latach spędzonych w Monachium przywiózł do Warszawy umiejętności malarskie na dobrym poziomie oraz przekonanie, że aby malarstwo mogło pełnić funkcję patriotyczną, musi zyskać uznanie Zachodu, a zyska je, jeśli będzie proste, zrozumiałe i prawdziwe artystycznie, tj. jeśli będzie wywoływało iluzję świata rzeczywistego.

Na poddaszu warszawskiego Hotelu Europejskiego założył pracownię malarską i rozpoczął działalność artystyczną. Nie przyniosła mu jednak ona sukcesu. Szybko się zorientował, że w krajowej krytyce króluje niepodzielnie idealistyczny akademizm, a największym autorytetem cieszy się Henryk Struve, profesor filozofii na Imperatorskim Warszawskim Uniwersytecie oraz autor publikowanych w warszawskiej prasie artykułów estetycznych i felietonów o malarstwie. Iżby więc utorować drogę do uznania społecznego młodemu polskiemu malarstwu realistycznemu, w tym jego własnemu, podjął walkę ze Struvem i jego akolitami, a zaczął ją szybko, choć zrazu nie był do niej jeszcze przygotowany ani intelektualnie, ani pisarsko.

Okazją do tego był artykuł Struvego o obrazie Aleksandra Wagnera Wyścigi w Cyrku Rzymskim, w którym krytyk ów dostrzegł prawdę artystyczną oraz ideę symbolicznego przedstawienia „momentu z życia umierającego Rzymu” (Struve 1875: 11). Witkiewicz w sposób szyderczy zakwestionował zarówno realizm obrazu, jak i jego ideę, ale nie kryterium prawdy artystycznej. Pisał: „[... ] przyjrzyjcie się tym rozhukanym hetkom, a przyznacie, iż pierwszy lepszy szlachcic ukraiński podobne, ba!, nawet lepsze wyścigi na swoim podwórku dać może. [...] W dodatku przednia grupa jest nędznie rysowaną, i wcale nie leci, ale wisi jakby na pasach w powietrzu” (Witkiewicz 1875: 143). 
Po kilkuletnim milczeniu objawił się Witkiewicz jako autor felietonów o malarstwie, publikowanych w latach 1884-1887 w warszawskim tygodniku ilustrowanym „Wędrowiec” Artura Gruszeckiego, w którym pełnił funkcję kierownika artystycznego. Były to w większości teksty o charakterze bardziej lub mniej polemicznym w stosunku do Henryka Struvego i jego stronników. Zebrane artykuły wydał Witkiewicz w roku 1891 w formie książki Sztuka i krytyka u nas.

Główną bronią teoretyczną Witkiewicza była definicja dzieła sztuki przejęta przezeń od Antoniego Sygietyńskiego, publikującego już wcześniej w prasie warszawskiej relacje z paryskich salonów. Sam zaś Sygietyński definicję tę przejął od Emila Zoli. Witkiewicz wielokrotnie ją parafrazowal, a także przytaczał zarówno w brzmieniu oryginalnym, jak i w tłumaczeniu Sygietyńskiego: „dzieło sztuki to wycinek rzeczywistości widziany przez pryzmat temperamentu artysty" (np. Witkiewicz 1884: 224). Od Sygietyńskiego przejął Witkiewicz także przekonanie, iż definicja ta trafnie ujmuje istotę współczesnego malarstwa zachodnioeuropejskiego.

Definicja ta jest dwuczłonowa: pierwszy człon jest aleteiczny (prawda artystyczna), drugi zaś jest ekspresjonistyczny (wyraz indywidualności artysty). Jest to zarazem definicja aksjonormatywna: oba jej człony są kryteriami oceny dzieła malarskiego. Są to jednak kryteria odmienne i niewspółmierne. Witkiewicz, tak jak Sygietyński i Zola, przeważnie skupiał się na kryterium pierwszym, a wcale lub niewiele uwagi poświęcał drugiemu. Będąc praktykującym malarzem, ujął pierwsze kryterium w kategoriach środków artystycznych: aby obraz był prawdziwy artystycznie, musi mieć bezbłędną perspektywę geometryczną i powietrzno-kolorystyczną, musi mieć doskonały modelunek, światłocień i musi być zharmonizowany kolorystycznie. Stosując te kryteria, oceniał w licznych tekstach krytycznych obrazy wielu malarzy ${ }^{1}$. Wielokrotnie przytaczał też dewizę Flauberta „nie co, lecz jak”, jednak nigdzie jej nie rozwinął do postaci koncepcji, a jego sposób oceniania obrazów pokazuje, że w jego opinii temat dzieła realistycznego nie musi być realistyczny, realistyczny musi być tylko sposób przedstawienia świata. Tak oceniał np. obrazy Böcklina - ich fantastyczne tematy nie przeszkadzały mu uznać je za prawdziwe artystycznie. „Nie co, lecz jak” nie oznacza więc bezwzględnego prymatu formy nad treścią, ale podporządkowanie środków artystycznych celowi iluzyjnemu. Witkiewiczowi zdawało się, że odkrył istotę malarstwa i jego generalny trend ewolucyjny prowadzący (meandrami) od malarstwa nieudolnego artystycznie do malarstwa prawdziwego artystycznie, wywołującego najdoskonalszą z możliwych do osiągnięcia środkami malarskimi iluzję oglądu fragmentu świata rzeczywistego.

Natomiast powtarzany hasłowo wymóg obecności w dziele wyrazu indywidualności artysty przydał się Witkiewiczowi jako oręż polemiczny wobec stawianego mu przez wielu polemistów zarzutu, że usiłuje on zredukować dzieło malarskie do kolorowej fotografii. Odpowiadał wówczas, że to nieprawda, bo od zawsze twierdzil, że prawdziwe dzieło sztuki nie może być tylko fotograficzną kopią natury, ale musi zawierać także wyraz indywidualności artysty. Ale nigdy nie sprecyzowal, na czym on polega. Zachodzi więc pytanie, w czym się może objawiać indywidualność artysty? Z całą pewnością nie w czymś innym, jak tyl-

\footnotetext{
1 Widać w tym wyraźny wpływ idei zawartych w traktacie o malarstwie Leonarda da Vinci, opublikowanym parę lat wcześniej w przekładzie Wojciecha Gersona. Witkiewicz nigdzie się jednak na to dzieło nie powołał.

2 Flaubertowską dewizę przejął Witkiewicz prawdopodobnie także od Sygietyńskiego, który omawiając nowe malarstwo europejskie, postawił diagnozę, że obecnie "nie zważa na to, co się maluje, ale jak się maluje”. Zob. Sygietyński 1884: 427.
} 
ko w przełamywaniu zasad malarstwa „fotograficznie” przedstawiającego rzeczywistość. Nie był jednak Witkiewicz senior konsekwentny w swych poglądach na temat fotografii, bowiem w polemice z najpoważniejszymi krytykami, którzy zarzucili mu sprowadzanie malarstwa do fotografii - Stanisławem Tarnowskim i Marianem Morawskim - napisal, że mają oni naiwne wyobrażenie o fotografowaniu, widząc w nim pracę czysto mechaniczną, a przecież fotograf musi wybrać obiekt, ustawić kadr, przesłonę itd., co pozwala na tworzenie dzieł zindywidualizowanych, a tym samym artystycznie wartościowych, czego znakomitym przykładem są fotografie Julii Cameron (Witkiewicz 1971: 192, 202).

Rzeczone dwa człony definicji dzieła malarskiego wiodą do rozbieżnych implikacji artystycznych. Prawda bez ekspresji (w jego rozumieniu) prowadzi faktycznie do malarstwa podobnego do kolorowej fotografii, ale z rozszerzeniem na irrealizm tematyczny realizowany realistycznymi środkami artystycznymi. Natomiast ekspresja bez prawdy artystycznej kieruje ku wszelkim możliwym irrealizmom.

$\mathrm{Z}$ aleteicznego punktu widzenia Witkiewicz senior oceniał także prace swojego dorastającego syna, licząc na to, że stworzy on arcydzieło naturalistyczne, a gdy junior zapisał się do krakowskiej Akademii Sztuk Pięknych - aby zniechęcić go do studiów, gromil, że się niczego tam nie nauczy, że już cztery lata wcześniej umiał więcej „niż to, co oni dzisiaj wystawiają", że miał on już jako dziecko dumę artysty, a teraz przenosi odpowiedzialność za swoją sztukę „na jakąś parszywą - każda jest parszywa - szkołę” (Witkiewicz 1969: 277). Zaś o Stanisławskim, w którego pracowni znalazł się syn, napisał mu w liście, że jego właściwości są takie, „jak właściwości aparatu fotograficznego $[. .$.$] bez korekty innych władz$ umysłowych", czyli że jego obrazy, tak jak fotografie, nie zawierają owego wyrazu indywidualności (ibid.: 287) .

Tymczasem junior, ulegając współczesnym „awangardzistom”, przede wszystkim Gauguinowi i kubistom, coraz bardziej negatywnie nastawiony był do wszelkiego naturalizmu. Mając lat 26, postawił sprawę jasno: ojciec jest naturalistą, a on naturalistą być dłużej nie chce. Ojciec dopiero trzy lata później, w obliczu zbliżającego się kresu życia, dał synowi artystyczne błogosławieństwo na pójście własną, nienaturalistyczną drogą twórczą. Uczynił to z miłości ojcowskiej, ale wbrew sobie jako artyście.

W owym czasie naturalizm był już w zasadniczym odwrocie, a w ciągu następnej dekady stał się kierunkiem niszowym. Zwycięski modernizm wyparł naturalizm na cmentarzysko przebrzmiałych stylów i wydawało się wtedy, że na zawsze. Atoli naturalizm wrócił w okresie przełomu postmodernistycznego jako nowy realizm, hiperrealizm i foto-art, a potem - new old masters i jest teraz jednym z nurtów współczesnego postmodernistycznego pluralizmu artystycznego w malarstwie. Chociaż Witkiewicz nie przewidział możliwości pluralizmu zrównującego aksjologicznie różne typy malarstwa, to jego opracowanie warunków artystycznych, jakie musi spełniać malarstwo naturalistyczne, nic nie straciło na ważności, gdyż jest trafną konceptualizacją sztuki dążącej do iluzji wizualnej.

Gdyby natomiast zaktualizować jego postulat, że należy tak tworzyć, aby zyskać uznanie Europy, to w warunkach radykalnego pluralizmu należałoby postulować, by nasze malarstwo rozwijało się wszechstronnie. A ponieważ de facto rozwija się wszechstronnie - od neoabstrakcji do nowego realizmu - toteż przyjmując generalną perspektywę aksjologiczną

\footnotetext{
3 Notabene zapowiedzi napisania studium porównawczego malarstwa i fotografii Witkiewicz nie spełnił.
} 
Witkiewicza, można uznać, że współczesne malarstwo polskie ją spełnia (zob. Tarnowski 2015: 46-50).

\section{Koncepcja i praktyka stylu zakopiańskiego}

$\mathrm{Z}$ powodu dolegliwości wywołanych gruźlicą zaczął Witkiewicz od roku 1886 bywać w Zakopanem, które doktor Tytus Chałubiński odkrył już wcześniej jako miejsce skutecznie łagodzące objawy tej nieuleczalnej wówczas choroby. A w 1890 roku osiedlił się tam Witkiewicz wraz z żoną i pięcioletnim synem - późniejszym Witkacym - na stałe. Pisywał w owym czasie do prasy warszawskiej esejo-reportaże $\mathrm{z}$ wycieczek w Tatry oraz swoje spostrzeżenia na temat góralskiej sztuki ludowej, w szczególności budownictwa góralskiego, w którym zachwyciło go mistrzostwo ciesielskie i dekoracyjne, górujące nad budownictwem ludowym innych regionów kraju (por. fot. w niniejszym tomie, s. 14, 16). Szybko powziął pomysł, iżby na podstawie form budownictwa, sprzętarstwa i ornamentyki górali podhalańskich stworzyć dostosowany do potrzeb nowoczesnego użytkownika nowy, a przy tym narodowy styl w architekturze i rzemiośle artystycznym, który nazwał „stylem zakopiańskim”. Dla perswazyjnego wzmocnienia swej idei wymyślił tezę, że w budownictwie, rzemiośle i ornamentyce góralskiej przetrwały relikty ogólnopolskiej sztuki przedkazimierzowskiej, więc wzorując się na nich, można stworzyć pierwszy narodowy, prawdziwie polski styl artystyczny - przede wszystkim w architekturze, ale także w meblarstwie i wzornictwie. Pragnął, by styl zakopiański rozprzestrzenił się na terenie całej przedrozbiorowej Rzeczpospolitej Obojga Narodów i objął wszystkie typy budownictwa. Sam zaś przystąpił do projektowania i budowania w Zakopanem rękami góralskich cieśli („budarzy”) willi w owym skonceptualizowanym przez siebie stylu zakopiańskim (zob. Tarnowski 2014: 387-390). Były to kolejno budowane wille: Koliba (1893), Pepita (1893), Korwinówka, Oksza (1896; por. fot. s. 26), Zofiówka (1896), Pod Jedlami (1898; por. fot. s. 38), Konstantynówka (1902), a także sanatorium dra Hawranka, obecnie Rialto (1898), kaplica Najświętszego Serca Pana Jezusa (1905; por. fot. s. 61) i kapliczka Korniłowiczów na Bystrem (1907) oraz dwa obiekty, w których styl zakopiański jest zmieszany z ciesielską tradycją litewską: Kaplica św. Krzyża braci Albertynów (1898) i budynek dworcowy w Syłgudyszkach na Litwie (obiekt ten nie zachował się; jego zdjęcie zob. w: Jabłońska 2008: 172). Z inspiracji Witkiewiczowskiej koncepcji i praktyki stylu zakopiańskiego wznosili wille drewniane także inni: zarówno zawodowi architekci, jak i góralscy cieśle (np. Jan Obrochta i Wojciech Roj). O stylu zakopiańskim dowiadywała się też zagranica. Model Domu pod Jedlami został pokazany na Wystawie Światowej w Paryżu w 1900 roku, a projekt willi w stylu zakopiańskim Franciszka Mączyńskiego zwyciężył w konkursie na nowoczesną willę ogłoszonym przez francuskie pismo „Moniteur des Architectes” w tym samym roku. Wówczas, na przełomie stuleci, wydawać się mogło, że nic nie stoi na przeszkodzie, by marzenie Witkiewicza o upowszechnieniu architektury w stylu zakopiańskim na cały obszar przedrozbiorowej Rzeczpospolitej się spełniło.

Rozumiał jednak Witkiewicz to, że propagowanie stylu zakopiańskiego poza Podhalem, a szczególnie w miastach, wymagało jego „translacji” w materiały trwałe - kamień, cegłę i beton. A ponieważ nie był zawodowym architektem, usiłował zjednać dla 
tego celu profesjonalnych budowniczych i architektów. Przy ich fachowej pomocy stworzył dwa obiekty murowane: dwór Jana Steckiego w Łańcuchowie pod Lublinem (1904) oraz gmach Muzeum Tatrzańskiego w Zakopanem (1913-1922) zaprojektowany z pomocą Franciszka Mączyńskiego, który także kierował budową tego obiektu (por. fot. s. 64). Zawodowi architekci sami też projektowali obiekty murowane $\mathrm{w}$ formach inspirowanych - mniej lub bardziej - Witkiewiczowską koncepcją i praktyką stylu zakopiańskiego. W Zakopanem powstały m.in.: plebania przy nowym kościele (Tadeusz Stryjeński, 1898), Sanatorium Dłuskich (Wandalin Beringer, 1902; por. fot. s. 76), Dworzec Tatrzański (Wandalin Beringer, 1903; por. fot. s. 86), hotel Stamary (Eugeniusz Wesołowski, 1904; por. fot. s. 94), gmach poczty (Eugeniusz Wesołowski, 1905), pensjonat Sanato (Eugeniusz Wesołowski, 1913), willa dra Różyckiego (Franciszek Mączyński, 1913; por. fot. s. 110), zakład wodoleczniczy dra Chramca (Jan Peroś, 1915), budynek Banku Spółdzielczego (Marian Heitzman, 1922; por. fot.s. 113), sanatorium dziecięce (Jan Witkiewicz Koszczyc, 1927; por. fot. s. 124). Z takiej samej inspiracji powstawały także dzieła poza Podhalem, m.in. gospoda w Ostrowach Górniczych (Franciszek Lilpopp i Karol Jankowski, 1893) i kamienica przy ul. Chmielnej w Warszawie (Jarosław Wojciechowski, 1907; por. fot. s. 132) czy budynek Ludowego Uniwersytetu Orkanowego w Gaci k. Przeworska (Jan Witkiewicz Koszczyc, 1935). (Informacje o tych obiektach i ich zdjęcia zob.: Tondos 2003; Jabłońska 2008; Moździerz 2013).

Celem pozytywnym idei i praktyki stylu zakopiańskiego było - powtórzmy - stworzenie pierwszego w historii polskiej kultury stylu narodowego i powszechnego. Natomiast celem negatywnym było wyparcie z Podhala form tyrolskich, propagowanych przez narzuconych przez władze zaborcze kolejnych dwóch dyrektorów zakopiańskiej Szkoły Przemysłu Drzewnego (Neužila i Kovátsa) oraz ich wychowanków i zwolenników, także wśród góralskich budarzy. Drugi cel w ciągu dekady został osiągnięty. Pierwszy cel był bardzo nierealny, więc powieść się nie mógł. Po pierwsze dlatego, że gdy Witkiewicz przystąpił do swojej kampanii o styl zakopiański, to wielkomiejscy architekci byli zwolennikami historyzmu-eklektyzmu, z którego perspektywy styl zakopiański traktowano jako nienadający się do przeniesienia do architektury miejskiej. Po drugie dlatego, że nawet zwolennicy Witkiewicza, skupieni w Towarzystwie Polska Sztuka Stosowana, szybko zaczęli propagować ideę korzystania w nowej twórczości z dziedzictwa ludowego także innych regionów przedrozbiorowej Rzeczpospolitej i nie tylko chłopskiego, ale także szlacheckiego. Z ich perspektywy styl zakopiański był jednym z wielu możliwych nowych regionalizmów, a jego narzucanie innym regionom było bezpodstawne. TPSS propagowało swoją koncepcję najpierw w wydawanych przez siebie zeszytach, a potem organizując (wraz z Delegacją Architektów Polskich) w 1912 roku na krakowskich Błoniach Wystawę architektury i wnętrz $w$ otoczeniu ogrodowem. Architektura tradycjonalistyczna, zarówno korzystająca z dziedzictwa chłopskiego i szlacheckiego („styl dworkowy”), jak i wielkostylowego (narodowy historyzm), słabła jednak pod wpływem wzrastającego naporu radykalnie antytradycjonalistycznego modernizmu, tak że w połowie okresu międzywojennego stała się już nurtem niszowym (zob. Tarnowski 2013: 233-236). Nawet w Zakopanem nowo wznoszone obiekty miały już coraz modniejsze wówczas formy modernistyczne.

$\mathrm{Na}$ początku lat trzydziestych usiłował ożywić zainteresowanie społeczeństwa i architektów stylem zakopiańskim jego miłośnik, inwestor i właściciel najwspanialszej witkiewiczowskiej willi zakopiańskiej - Domu pod Jedlami - Jan Gwalbert Pawlikowski, 
organizując ankietę $\mathrm{w}$ tej sprawie i publikując jej wyniki w redagowanym przez siebie roczniku „Wierchy”. Jej rezultat był jednak odmienny od oczekiwanego. Co prawda większość uczestników doceniła wartość witkiewiczowskich willi w stylu zakopiańskim i uznała potrzebę kontynuacji, ale nie jako stylu ogólnopolskiego, lecz regionalnego. Ambicje Witkiewicza, by translować go w mur w architekturze monumentalnej, zostały uznane za chybione, gdyż wysoki dach dwuspadowy (półszczytowy) w obiekcie o dużych gabarytach musi być zastąpiony szeregiem małych daszków, co zmienia proporcje bryły, zbliżając ją do prostopadłościanu. Ze stylu zakopiańskiego zostałyby w gruncie rzeczy tylko owe półszczytowe daszki. Najsilniejszy jednak argument przeciwko takiej translacji przedstawił bratanek Witkiewicza - Jan Witkiewicz Koszczyc - w cyklu artykułów opublikowanych w tym samym czasie w tygodniku „Zakopane”. Chociaż werbalnie opowiedział się za możliwością przeniesienia stylu zakopiańskiego w mur, to jednak zrobil istotne zastrzeżenia, których implikacje nie potwierdzały jego deklaracji. Napisał bowiem, że skoro istotę budownictwa góralskiego stanowi jego konstrukcyjność, to nonsensem jest imitowanie w materiałach trwałych ściany zrębowej, gdyż w żelbecie odpowiednikiem konstrukcyjnym zrębu z płazów jest konstrukcja płytowo-słupowa. A jeśli do konstrukcji słupowo-płytowej dodamy ściany osłonowe i płaski dach, to otrzymamy prostopadłościan, niemający nic wspólnego z bryłą zakopiańskich willi Witkiewicza. I tak właśnie Koszczyc projektował swe największe dzieła - budynki Szkoły Głównej Handlowej w Warszawie 4 .

Dążenia Witkiewicza do stworzenia ogólnopolskiego stylu w architekturze i sztuce użytkowej opartego na góralskiej tradycji ludowej nie miały, rzecz oczywista, szans na realizację i zasięg jego rozpropagowania w gruncie rzeczy ograniczył się do Zakopanego i okolic. Ale i to było wielkim osiągnięciem, gdyż Zakopane stało się pierwszym ośrodkiem architektury wzorowanej na polskiej tradycji ludowej, choć ograniczonej tylko do góralszczyzny. Dzięki temu Podhale, jako jedyny region Polski, zyskało swą wyraźną lokalną tożsamość architektoniczną. Natomiast bardziej odległy wpływ Witkiewicza - w wersji już silnie zmodernizowanej - można dostrzec w obsypanej nagrodami ekspozycji polskiej na wystawie paryskiej Nowoczesna sztuka dekoracyjna i przemystowa w 1925 roku (zob. Sieradzka 2002: 196-207).

Modernizm lat trzydziestych, a potem powojenny socmodernizm, stłumiły wszelki tradycjonalizm $\mathrm{w}$ architekturze, $\mathrm{w}$ tym zarówno historyzm, jak i neowernakularyzm. W pierwszych latach po II wojnie światowej powstało jeszcze kilka obiektów nawiązujących do tradycji stylu zakopiańskiego, m.in. gospoda w Kuźnicach (Anna i Michał Górscy, 1958) i Dom Turysty w Zakopanem (Tadeusz Brzoza i Zbigniew Kupiec, 1959), ale późniejsze państwowe inwestycje były już tylko modernistycznymi płaskodachowymi „klockami”, zaś murowane „wille” góralskie były też „klockami”, ale z wielokondygnacyjnymi spadzistymi dachami pokrytymi blachą cynkowaną lub eternitem.

W architekturze światowej zasadniczą zmianę przyniósł przełom postmodernistyczny, jaki na Zachodzie dokonał się na początku lat siedemdziesiątych XX wieku, a którego sensem generalnym było zanegowanie dokonanego przez modernizm odrzucenia tradycji. Architektura „wysoka” ponownie otwarła się na dziedzictwo historyczne, w tym wernakularne i neowernakularne. Zakopiańszczyzna powróciła w nowej architekturze Podhala w szerokim spektrum: od prostej kontynuacji witkiewiczowskiego stylu zakopiańskiego do

${ }^{4}$ Ozdobił je tylko quasi-akroterionami i bardzo oszczędną polichromią. 
postmodernistycznych jego trawestacji (zob. Tarnowski 2012: 231-261; Moździerz 2013). To, co było nie do pojęcia z perspektywy radykalnie antytradycjonalistycznego modernizmu, mianowicie, że można modernizować architekturę przez odwołanie się do tradycji w tym przypadku do tradycji stylu zakopiańskiego - po przełomie postmodernistycznym stało się faktem. Dziedzictwo stylu zakopiańskiego znowu jest żywe, nie tylko zresztą na Podhalu. Karczmy i zajazdy w formach wzorowanych na stylu zakopiańskim powstają w całej Polsce, od Tatr i Karkonoszy po Bałtyk, nawet w bezpośrednim sąsiedztwie sopockiej plaży (co bywa także przedmiotem silnej krytyki). Koszczyc uległ był modernizmowi, widząc w stylu zakopiańskim głównie konstrukcyjność oraz ignorując formę, miał jednak niewątpliwie rację, krytykując imitowanie w materiale trwałym form uzyskanych w drewnie. Beton zbrojony, stal i szkło, szczególnie jeśli są skombinowane z materiałem drewnianym, dają ogromne możliwości formotwórcze, także w dziedzinie swobodnego parafrazowania tradycji stylu zakopiańskiego. Zakopane stało się naturalnym zagłębiem twórczego poszukiwania takich postmodernistycznych trawestacji. W panoramie miasta wyróżniają się dzieła Stanisława Tylki (por. fot. s. 114), Anny i Rafała Rafaczów (por. fot. s. 134) oraz Jana Karpiela i Marcina Steindela. Z wyjątkiem kościoła są to obiekty średniej wielkości.

W swoich najlepszych realizacjach owa postmodernistyczna zakopiańszczyzna wpisuje się w światowy postmodernistyczny neowernakularyzm jako jego pełnowartościowy nurt. Po okresie modernistycznej refutacji architektura Podhala powróciła do normalnego trendu rozwojowego, polegającego na niekończącym się łańcuchu modernizacyjnym bez zrywania z historycznym dziedzictwem. Styl zakopiański ma ogromny potencjał, a w jego obrębie nadal ma go typ drewnianej willi witkiewiczowskiej, o czym świadczy najnowsze dzieło pracowni Karpiel-Steindal (por. fot. s. 140). Kiedy zanikł krępujący twórczość architektoniczną wymóg negowania tradycji, każde historyczne źródło inspiracji może stanowić punkt wyjścia dla nowej wartościowej twórczości, a dla Podhala najlepszym źródłem inspiracji jest tradycja stylu zakopiańskiego.

\section{Bibliografia}

Jabłońska, Teresa 2008. Styl zakopiański Stanisława Witkiewicza. Olszanica: BOSZ.

Kosiński, Kazimierz 1928. Stanisław Witkiewicz. Warszawa: Instytut Wydawniczy „Bibljoteka Polska”.

Moździerz, Zbigniew 2013. Architektura i rozwój przestrzenny Zakopanego (1600-2013). Zakopane: Zakopiańskie Studio Wydawnicze Halny.

Piasecki, Zdzisław 1983. Stanisław Witkiewicz. Młodość i wczesny dorobek artysty. Warszawa-Wrocław: PWN.

Sieradzka, Anna 2002. „Art déco w Polsce”. W: Pierre Cabanne, Encyklopedia art déco. Tłum. Joanna Guze. Warszawa: Wydawnictwa Artystyczne i Filmowe, Wydawnictwo Naukowe PWN.

Struve, Henryk 1875. „Aleksander Wagner i obraz jego Wyścigi w Cyrku Rzymskim”, Kłosy 20, 497: $10-11$.

Sygietyński, Antoni 1884. „Z literatury i sztuki: na rynkach europejskich sztuki”. Wędrowiec 36: 425-428.

— 1951. „Album Maksa i Aleksandra Gierymskich”. W: Antoni Sygietyński. Pisma krytyczne. Warszawa: Państwowy Instytut Wydawniczy. 
Tarnowski, Józef 2012. „Styl alpejski w środkowej Europie i polska kontrakcja wobec niego - styl zakopiański". Estetyka i Krytyka 25: 231-246.

— 2013. „Czy powrót modernizmu w architekturze?”. W: Teresa Pękala (red.). Powrót modernizmu?. Lublin: Wydawnictwo Uniwersytetu Marii Curie-Skłodowskiej.

- 2014. Wielki przełom: studium $z$ estetyki Stanistawa Witkiewicza. Gdańsk: Wydawnictwo Uniwersytetu Gdańskiego.

— 2015. „Wieża Babel dyskursu nowoczesności”. W: Jacek Bielak, Józef Tarnowski (red.). Nowoczesność w sztuce i w myśli o sztuce na Pomorzu od XIX do XXI wieku. Gdańsk: Oddział Gdański Stowarzyszenia Historyków Sztuki.

Tondos, Barbara 2003. Styl zakopiański i zakopiańszczyzna. Wrocław: Zakład Narodowy im. Ossolińskich.

Witkiewicz, Stanisław 1875. „Szanowny Redaktorze!”. Opiekun Domowy 9: 143-144.

- 1969. Listy do syna. Warszawa: Państwowy Instytut Wydawniczy.

- 1971. Pisma zebrane. T. 1: Sztuka i krytyka u nas. Kraków: Wydawnictwo Literackie.

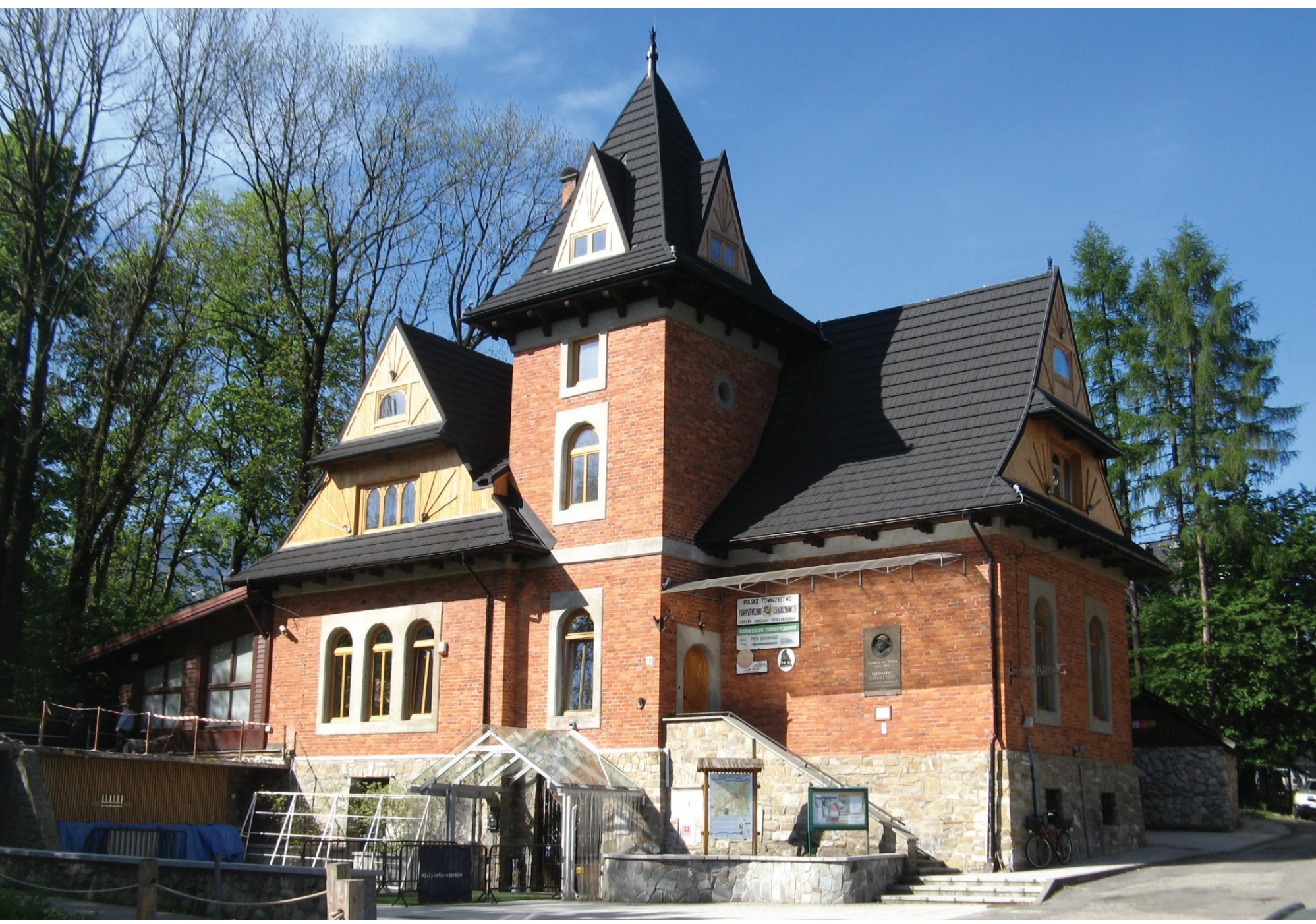

Wandalin Beringer, „Dworzec Tatrzański”,

Zakopane, 1903

Fot. Józef Tarnowski 